\title{
The Production of the Francophone: A Discursive Construction
}

Jean-Marie Klinkenberg ${ }^{a}$

\begin{abstract}
The present research proceeds with a discursive analysis of the major phases in the evolution of discourse on the French-speaking world on the one hand and the French-speaking person on the other: when these two objects are being constituted, a strong convergence between them appears, followed by a spectacular divergence; a divergence that will produce ambiguities and confusions whose effects on representations, positions and actions will be studied. The study concludes that it is necessary to take into account the specific characteristics of each of the cultural areas of the Francophonie.
\end{abstract}

Keywords: Francophonie. Discursive analysis. Historical evolution. Ideology.

a Universidade de Liège, Departamento de Línguas e Literaturas Românicas. Liège, Bélgica.

E-mail: jm.klinkenberg@uliege.be

How to cite:

Klinkenberg, J-M. The Production of the Francophone: A Discursive Construction. Gragoatá, 
${ }^{1}$ On the 3 rd of October 2012, first

day of the colloquium

"La construction

discursive du 'locuteur

francophone' en

milieu minoritaire.

Problématiques,

méthodes et enjeux"

where this conference

what given, Google

showed $57,700,000$

"francophone"

to $2,880,000$

"francophonie" ; on

the $29^{\text {th }}$ of October,

2015, day of the

proofreading of its text

the ratio was $31,800,000$

"francophone"

to $11,400,000$

"francophonie", a

smaller proportion but

still significative.

${ }^{2}$ In 2012. Which is still much compared to the champion of discretion "la [feminine definite article] francophone", of which only 22,900 occurrences were recorded at the same date.

\footnotetext{
${ }^{3}$ The former [francophonie] was first - and often still is - defined as the community of the latter [francophones]. Even when the word "francophone" is adjective, it often still has much to do with the francophonie: when the word that accompanies it refers to an entity, an institution, or an abstract concept (for example in "the francophone world"), it is its synonym.
}

\section{Francophonie and the francophone}

Asking what "Francophone" is the name for, or studying the way in which this concept was constructed, presupposes that we first examine the constitution of the concept of "francophonie". This assertion may seem paradoxical, since the second notion seems so subordinate to the first. Not only does the word "francophonie" appear to be genetically derived from "francophone", but it is much less used than it is".

However, it is indeed the concept of "francophonie" that has become the first in our intellectual concerns: it is the one that has triggered the richest discursive creations; it is also the one that has generated the most debates, controversies and studies; and if the history of the concept of "francophonie" has yet to be written - a modest contribution to it is the subject of the present contribution - the history of the francophonie is beginning to be known.

Moreover, the apparent primacy of the word 'francophone' should not be an illusion: when it appears, the term is in fact most often an adjective. An examination of its first 1,000 appearances on the web shows that it is substantive in only $7 \%$ of cases: "le francophone" is a rarity with 42,000 appearances".

The Francophone is therefore an unknown, whose fate is closely linked to that of the much-discussed French-speaking world ${ }^{3}$. And studying the discursive constitution of the Francophone will therefore, in some respects, be impossible to separate from a study of the discursive constitution of the French-speaking world. Comparing the major phases in the evolution of discourse on each of these objects will be undeniably relevant: we will see that at the moment they are constituted, a strong convergence manifests itself between them, but that a spectacular divergence then occurs; this divergence is such that the survivals of the first discourses at these subsequent stages produce ambiguities and confusions, the effects of which are not small on our consciences, our representations, and therefore no doubt also on our positions and actions. 


\section{The discursive construction of the French-speaking world}

A scientific trend has developed over the last ten years which has led to the advent of a metadiscourse that overlooks the very concept of the French-speaking world. It is striking to note that, carried out in different geographical and institutional locations, with different techniques, this new research is converging in that it allows us to deconstruct the images and concepts woven into the French-speaking discourse by highlighting their genesis, their evolution, and the ways in which they are activated.

I will take just two manifestations of this new current, the most spectacular in my eyes. These are the works of Georg Glasze from the University of Erlangen, carried out from the place that is the new cultural geography, and those of François Provenzano, from the University of Liège, carried out with the tools of rhetorical analysis, works that confirm and explain what had obviously not escaped the critical observer of the French-speaking world: that it is a discursive construction.

In the paradigm that is "Neue kulturgeographie", the entities that are nation-states or regions have ceased to be almost naturalised objects, presenting intrinsic qualities that make it possible to identify, describe and delimit them, but have become the contingent product of various processes that institute them, processes that are always accompanied by a discursive construction whose function is to produce effects of evidence. Political communities are thus perceived - or exist, which is the same in the eyes of a constructivist - through the actors who create them.

The French-speaking world, both as an international political actor and as an anthropological horizon, does not escape the rule, nor will the Francophone escape it. Glasze (2006a, 2006b, 2010) distinguishes three phases in the constitution of the francophonie object, phases which I describe here in a cursive manner.

The concept took shape, in the 1960s, during the decolonisation process. The francophonie was first built as a community cemented by language. As a whole defined by a colonial past, minus the colonial link: all the witnesses insist, almost heavily, on the lifting of this mortgage. Although the 
rupture of the colonial link is proclaimed in francophone discourse, the filiation of the latter with the gallocentric discourse is nevertheless clear: the French language is presented there as the vector of a universalist and humanist ideal, and the rhetoric which institutes this image reproduces the topos of the intrinsic superiority of French and the culture it conveys.

Second stage: in the 1970s and 1980s, critics protested against the possible neo-colonial character of the Frenchspeaking world. This led the latter to reformulate its discourse in a radically different way. This criticism was obviously reinforced, if not caused, by the changes in the international context, which then imposed a definitive abandonment of the first model.

We can speak of a $180^{\circ}$ turn, because, in this mutation, the language is going to fall by the wayside. Thanks to a close lexicometric study, Glasze thus shows that from 1969 onwards, the expression "French language", which had hitherto been widely dominant, slowly gave way to three lexical sets, organised around two themes - peace and democracy - and the idea of francophonie. In the course of this process of delinguisation, the word "francophonie" did not make its appearance - it was already there, biding its time - but made a double breakthrough. On the one hand, it defeats its rivals (such as "gallicity" or "frankness", which held the line for a while); on the other, it sees its semantics narrowing, as will that of "francophone" at the same time. This restriction does not mean, however, that the content of the term is very clear-cut. In any case, a statement such as "Gabriel, emptying his fifth grenadine, perished in front of an assembly whose attention seemed all the more attentive as the francophonie was more dispersed there", which we could read in 1959 in Raymond Queneau's Zazie dans le métro, has now become obsolete: who would still use "francophonie" in the sense of "set of competences in the French language"?

The third phase began at the end of the 1990s. It may appear to be a continuation of the previous one, except that the values proclaimed during the second phase crystallise and become institutionalised. It was then that the International Organisation of the Francophonie defined the latter as the space of cultural diversity, and therefore as an alternative to the 
${ }^{4}$ For example,

Provenzano points out that the 1980s are the moment when "is constituted more and more explicitly a socio-institutional paradigm of literary studies that precisely reevaluate the whole historiographic tradition". homogenisation resulting from globalisation (counter-values materialised in the domination of English). On the one hand, the abandonment of the linguistic criterion is confirmed, as is the synonymy between cultural diversity and francophonie; on the other hand, new themes are associated with the former and revolve around them: to democracy and peace are added sustainable development and dialogue between cultures.

The work of François Provenzano (2006, 2011a, 2011b) starts from a different horizon: it aims to contribute to the reflection aimed at providing Francophone studies (whose birth is very painful; KLINKENBERG, 2014) with a solid epistemology; to this end, it combines the contributions of the sociology of culture with those of the analysis of texts, a necessary articulation because the postures of the actors refer to the institutional framework, which is therefore the place of conditioning of the Francophone cultural discourse.

This work confirms Glasze's description by showing to what extent the francophonie is 'a socio-historically conditioned and rhetorically structured discourse effect' (GLASZE, 2008, p. 13). They also confirm its phasing, but with different arguments ${ }^{4}$. One of their contributions, for example, is to establish that metaliterature plays a decisive role in the emergence and affirmation of so-called francophone literature. But they better show the ambivalence of this discourse. They show that in its rhetoric, the francophonie has constantly tried to associate, as best it can, two largely contradictory themes. And it is obviously this contradiction that interests us here.

On the one hand, in its early days, the francophonie mainly relayed the traditional and monological discourse of French universalism (remember that, for Rivarol, French is no longer the French language, it is the human language). She thus caressed the utopia of a civilisation of the universal: By basing the francophone project on a cultural necessity, Senghor and the other participants in the historic issue of the journal Esprit refused to consider the power relations and material disparities between the former metropolis and the former colonies, the French language being worthy of enrichment and a common treasure (PROVENZANO, 2008, p. 45). But on the other hand, in the second and third stages, the observation of the diversity of situations in which Francophones live made it necessary to 
${ }^{5}$ See for instance the words of a specialist:

"B. Boutros Ghali spoke of French as "non-aligned language and solidarity language"

[...] and F. Mitterrand [...] succeeds in establishing the

Francophonie as a model of linguistic diversity and resistance to cultural and linguistic uniformization. It was a genuine discursive tour de force" estimates Bruno Maurer (2008, p. 85). For plurilinguism in Francophonie, though real, "is not the result of language policies by France and its southern allies, that never made space, in the 1990s, for national languages. It is rather the unwanted child of all-French educational policies that failed to educate the masses, particularly in Africa". add a second theme to the first, without denying the first one: the theme of "dialogue of cultures" and "cultural diversity", an euphemistic version of the struggles for symbolic recognition that animate Francophone minorities, defined by a linguistic dimension, such as Quebec, Acadia, for example, or the young African states.

Such a reconversion makes one dizzy. It makes the centripetal and the centrifugal coexist, and can only operate by producing a new image of the French language, as fantastical as the one that wanted to see it as a humanistic language in essence: that of a language that obviously creates a rather complex and not very legible system of values: the belief in a universally pure French to be preserved on the one hand, and the call for disinterested cultural exchange and métissage on the other, do not in any case lead to the same options in terms of management of cultural productions. All of this is not without producing ambiguities on various levels, particularly in terms of didactics ${ }^{5}$.

\section{The production of the francophone. Act I. A linguistic destiny}

Observing the history of the francophonie allows us to see that it is indeed a rhetorical construction, which has a history. A history made up of spectacular reversals: before becoming - belatedly - an object of study, the francophonie was a colonial concept, before becoming, at the start of the globalisation process, the cement of a culture of diversity. It can be hypothesised that these changes have had an impact on the conception of homo francofoniensis, and that the historical pattern that has emerged may, mutatis mutandis, underpin the evolution of the latter.

\section{The francophone as a unit of account}

The francophone is born first as a unit of account in evaluations relating to language services. I deliberately use a vague expression and not terms such as "language practices" or "language skills", for reasons that will become apparent.

This is a recent birth. We know that the word was invented by Onésime Reclus, who wrote it in 1886 in France, Algérie et Colonies, a book of which many passages were taken 
${ }^{6}$ E.g. Joseph

Hanse (personal communications).

${ }^{7}$ This opinion comes from the fact that, in the same texts, Reclus gave a definition of "francophonie" that did not coincide with its use of

"francophone" : the francophonie is to him "not the number of persons speaking French but the one of men among which French language reigns", or this "reign" itself (Examples : "the divorce line" leaves "to the "francophonie" the Val d'Anniviers", 1899 ; "the European francophonie",1899, p. 841, including France) Francophonie is, thus, a geopolitical space, or a property: on can speak for instance of a person's or a region's francophonie. It is found with this meaning in the writings of Franck F. Schoell ("the Geneva scene [has] a certain tendency to francophonie", 1936) or in an unpublished article by Anne Voisin, found in Maurice Piron's papers, pioneer in Francophone studies (unpublished archives, in my possession): francophonie

"designates either the quality of the one or the ones speaking French, either to the quantity of Frenchspeakers in a given region and mainly on the world-wide scale". up again shortly afterwards in La France et ses colonies (1889). The term then recurs in many other works by the same geographer, including Le plus beau royaume sous le ciel (1899), where expressions such as "francophones countries" and "francophones cantons" abound, defined as entities where French is an "official language" or a "national language" (a distinction that Reclus does not explain or question).

Invented by one man, the word will remain his property, and will disappear with him. It was not until the 1930s that it was reborn, and gradually became a widely shared term, always with a linguistic meaning (which is to be expected, of course, since this was the first stage in the discursive construction of the francophonie).

It was only in the 1960s that it became established again. Until then, and even afterwards, it remains in significant competition with other terms, such as "francoloque", "francisant" (which we find in the same Reclus, in Lâchons l'Asie, prenons l'Afrique [Let us drop Asia, let us take Africa], 1904, p. 279) or simply "Français" (which Reclus also uses: "en Prusse, 9000 Français Wallons...", 1899, p. 814). And we also know that it will be contested by purists ${ }^{6}$, shocked that the word designating a speaker of the most beautiful language in the world could appear in a paradigm alongside vulgar instruments such as the parlophone or, horresco referens, the hygiaphone. It will be contested in favour of inventions like Lépine's "francoglotte" or "gallicant", and it will be contested precisely at the moment when it is needed: rear-guard battles are, as we know, often the bloodiest.

\section{But what do we count?}

The important thing is the meaning that the word takes on in this first phase. Contrary to widespread opinion ${ }^{7}$, the word 'francophone' does not originally mean 'user of the French language', but rather 'speaker of French as a mother tongue' (emphasis added).

However, two clarifications need to be made to this definition. And we shall see that they are significant.

Firstly, being a native French speaker does not mean being of the Parisian standard variety. The French that the French-speaker finds in his or her cradle is rich in many 
varieties, which may at first sight seem surprising but which can be explained: Bourbon and Mauritius are thus at Reclus "two islands of French-speakers" (1899, p. 841). Even if the border between Creole and French is more blurred in Reclus' time than it is today, the fact remains that the globalisation of the various varieties in the same category - that of French, practised only by the elite, whether white or coloured - has something daring about it.

Moreover, in the chronological slice that concerns us, the word also appears with what seems to be another meaning. Let us read Reclus once again: in 1899 he noted that "...the number of French-speaking Nederduitsch or Lower Germans is increasing daily" (p. 815). Likewise, the geographer counts among the French speakers "about 2 million in Africa, including Arabs and Berbers capable of our (sic) idiom" (1899, p. 825). However, Dutch-speakers and Berbers are obviously not, by definition, maternal speakers of French.

This raises the question: in what capacity can users of Creole and Lower German be said to be French-speakers? This apparent correction to the definition of French-speakers as native speakers of French is by no means a precise description of the linguistic variety, nor is it dictated by a sociolinguistic concern. In fact, we are quite far from it. What we are concerned with here are not groups living in original diglossia situations or developing endogenous norms, but a very particular - and even paradoxical - fraction of 'mother-tongue francophones': francophones in the making, or at least in spe. To put it bluntly, these speakers are nothing more than market shares to be conquered. Giving them the beautiful name of "francophone" is to dub them; it is to give them the gift of the compass that will guide them towards their destiny; it is to set them a horizon, even a mission: to make them the new custodians of a collective and sacred treasure, over which only native French people could watch over until now.

In other words, what emerges in this discourse is less a definition anticipating the one that sociolinguistics could formulate today than a certain conception of the treasure in question: language. And if any discourse presupposes one (or more) enunciator(s) and one (or more) enunciatee(s), their portraits will be drawn here. 
The conception of the French-speaking person found during this first phase is thus implicitly structured by the distinction between two types of language. On the one hand, an ideal Language, inscribed in a universe of permanence and necessity, close to the world of ideas according to Plato (and which I will henceforth write with a capital letter); on the other, a daily, terrestrial language, that of the sublunar world, reigning over the contingent and the transient. The Language is thus seen in its unity, and not in its diversity; in its French specificity, and not in its linguistic generality: there should be only one French Language, beyond the variations that an objective examination of practices highlights (and so we explain how Reclus manages to make this observation and its Franco-centric conception coexist). To be a francophone, at this stage in the history of the concept, is therefore to repress variation. As Pierre Bourdieu (1982) points out, "to speak of the language, without any further precision [...] is to tacitly accept the official definition of the official language of a political unit". This operation is found in all linguistic communities, but is particularly spectacular in the case of French, which has, more than any other, equipped itself with powerful instruments for stabilizing and celebrating its language. From a chronological point of view, this position has its counterpart in fixism.

This cluster of features comes together in a single one: essentialism. I have thus called (KLINKENBERG, 2001, 2014, 2015) the ideological manoeuvre of construction that consists in wresting institutions from the contingency of history to make them an ever-already-there one. This manoeuvre mobilises a discourse which aims to make monolithic to consciences what is objectively only a conglomerate of linguistic varieties, which differ in their costs as much as in the profits they allow to be expected on the symbolic market. Essentialisation is therefore a form of naturalisation.

This naturalisation goes hand in hand with concealment of the subject. The myth of "genius" leads to the belief that language has an existence independent of the users; it displaces the discourse on language itself and obscures the work of these subjects; it makes it possible to describe the code "without relating this social process to the social conditions of its production and reproduction" (BOURDIEU, 1982, p. 39) and leaves the symbolic violence of exchanges in the shadows. I 
${ }^{8}$ This is very explicit in Reclus. "This 'us' expressed in the title [Let us drop Asia, let us take Africa] refers indeed exclusively to France alone, and note to the speaker community called elsewhere 'francophones' by Reclus. Those ones, for that matter, are not simply appointed as such, but are, to borrow the words of the geograph, 'accepted' as such by France: '...we accept as francophones all those who or seem to be destined to stay or become participants of our language' (Reclus, 1886, 422; our emphasis). The francophonie is thus designated elsewhere by Reclus as 'complete France' (Reclus, 1917, 165)" (PROVENZANO, 2006, p. 3). am talking about occultation, not elimination: seeing language as an in-self, cut off from its social determinations, does not necessarily mean forgetting this user who is made the subject of discourse by calling him or her "francophone". Rather, it means opposing this user to Language and, in this opposition, favouring the latter over the former. In the first phase of the development of the Francophone, we constantly see this guilt trip at work.

\section{The first Francophone and the first Francophonie}

This first phase therefore allows us to observe powerful harmonies between the concepts of the Francophone and the Francophonie. The latter was defined as a community cemented by a Language expressing a universalist ideal, and communicating in the intrinsic superiority of this centralised Language and the culture it conveys. The discourse on the Francophonie ultimately turns out to be a discourse on this Language. It is a timely contribution to the arguments which ensure the ideological and axiological construction of the francophonie. The unity and stability thus fantasised serve not to condemn or deny internal diversity, but to show how this diversity must be managed and animated. It will be animated by centripetal forces, and managed, it can only be managed by the centre, and even for the centre ${ }^{8}$. Because of course, the genius of this language is the genius of France. And this centrality cannot be questioned.

\section{The making of the francophone. Act II. An Identity}

The second francophone was born at a time when the concept of francophonie was getting rid of its strictly linguistic dimension.

The concept of the francophone seemed to escape this movement of delinguisation. There are two reasons for this. The first is that, while it is conceivable - difficult but conceivable - to expel the linguistic dimension from the definition of a community, it seems even more acrobatic in the case of an individual whose name is taken from a language. Moreover, this is precisely the period when the academic world - to which I shall return - is undertaking linguistic research on the issue. 
However, there is a parallel movement here to the one known as 'francophonie'. For the general public, the word will henceforth designate an identity, rather than language skills: if The use of 'francophonie' In Zazie dans le métro is now obsolete (or even agrammatic, one could say, forcing the metaphor), the use of 'francophonie' in this unforgettable novel is no less obsolete. ("A rather distinguished francophone expressed the common opinion: - And the Sainte-Chapelle? - Ah ah, said Gabriel and he made a grand gesture. - He will speak, said the polyglot lady to her fellow countrymen in their native idiom. »)

A distortion therefore appears between two meanings of the word "francophone": identity and linguistics. For, contrary to what the title of this paragraph suggests (Balzac: "Titles are always complete impostors'), it is not one but two francophones who are to be welcomed at this historical moment.

\section{The Francophone of linguists}

As indicated, the linguistic meaning will now be worked on by the academic world and, as a result, by the political world. Both are indeed involved in the development of counting methodologies, which themselves presuppose that the question of what constitutes a user of the French language is answered.

There is no question of retracing the history of this research here. Suffice it to point out that they are developing at a time when French linguistics is taking up the question of language variation, hitherto largely repressed. However, the work, which began early on - with such highlights as the colloquium on 'francophone ethnic groups' held in Nice in April 1968 (AAVV, 1969, 1971), the publication of Albert Valdman's Le Français hors de France (1979) and that of the Inventaire des particularités lexicales du français en Afrique noire (RACELLE-LATIN, 1983) - initially concerned only the language itself: The question of the francophone only really began to be asked with Le Français dans l'espace francophone (ROBILLARD; BENIAMINO, 1993, 1996) and above all with Chaudenson's "grid for analysing linguistic situations" (1988, 1991; CHAUDENSON; RAKOTOMALALA, 2004).

The articulation between academic and political concerns is powerfully signified by the fact that the International Organisation of the Francophonie has twice - the first time 
in June 2008, the second in October 2014 - organised an international seminar on the 'Methodology for observing the French language in the world'. The aim was to examine "the very notion of 'francophone' and to analyse in detail the calculation methods proposed by the Observatoire de la langue française and the ODSEF [Observatoire démographique et statistique de l'espace francophone] for estimating the number of francophones in the world" (http://www.francophonie.org/2eSeminaire-sur-les-methodologies.html). In any case, the O.I.F. is trying to avoid an insufficiently nuanced classification of situations in the French-speaking world (such as that which consists of distinguishing between 'real French-speakers' and 'partial French-speakers'). To this end, it translates the results obtained by interpreting various available sources (such as, for Europe, Eurostat and the Eurobarometer) into a typology of 'Francophone profiles' divided into 'three planets': the planet 'being born in French', the planet 'living (also) in French' and the planet 'choosing French as a foreign language' (WOLFF, 2014).

\section{An identity partially decoupled from language}

However, for the general public, the word 'francophone' refers less to language skills than to identity. Thus, being francophone is no longer a cultural destiny: it is an essence; or, at best, a marker of social belonging. And this essence no longer has a necessary link with linguistic practice. To demonstrate the divorce between the identity and language definitions of the francophone, I will use a few Belgian examples.

It was a real shock that shook the country when La Langue française dans le monde was published in its 2010 edition (WOLFF, 2010). This working tool estimated the number of Belgian francophones at 8.2 million: an impressive percentage of the 11 million people who live in the country's 11 million régnicoles. This figure led the Observatoire de la langue française to be very officially accused of imperialism: did it not annex, against its will, the majority of the population? For, it must be known, Belgian political life, as reflected in the language of political scientists and journalists, is structured by a cleavage between Dutch-speakers and French-speakers, these words referring to a kind of unofficial political status: 'the French-speakers' 
${ }^{9}$ Moreover, according to a well-established tradition (but recently undermined), the Prime Minister chairing the aforementioned council is recognized in Belgium as

"linguistic asexual" (expression coined in 1968 by Gaston Eyskens, Flemish Prime Minister at that time and perfectly lexicalized). Though the metaphor had a language and not an identity value, it would be logical to designate this character fatally driven to use both main national languages as "linguistic bisexual". is the block made up of the inhabitants of Wallonia (minus its protected German-speaking minority), a good proportion of the inhabitants of Brussels and the users of French in the 'communes à facilités' (municipalities with facilities). In total, a good four million people. However, true to its methodology, La Langue française dans le monde used the word as referring to a level of competence. The school curriculum is supposed to provide this competence. And, as a result, some pointed Flemish nationalist leader, because he was able to express himself in French, saw himself, in spite of himself, enlisted in the cohort of his opponents.

Further proof that the ethnonym 'francophone' is not an indicator of language competence is the terminology used to describe the Belgian federal government. This government must constitutionally have "as many French-speaking as Dutch-speaking ministers". However, if these terms - which in everyday usage are translated as 'French-speakers' and 'Dutch-speakers' - were to denote any expertise in 'French and Dutch expressions', a naïve observer would surely conclude that the Council of Ministers is composed of $100 \%$ Frenchspeakers (instead of 50\%) ${ }^{9}$. Finally, ethnonymic designations often appear in contexts where they are grammatically opposed to those referring to language skills. Examples: "she is French-speaking, but above all bilingual", "our interlocutor, still perfectly bilingual, but Dutch-speaking" (in the daily newspaper La Libre Belgique, 27.09.12, p. 8 and 9).

This essence no longer has a necessary link with linguistic practice, I wrote. But of course, at some point it needed language to build itself up.

For there is clearly a privileged link between language and identity (cf. KLINKENBERG, 2013). We know that there are potentially numerous elements of substratum that can lead to an identity formalisation: skin colour, clothing, food practices... Why, then, the privilege granted to language, and the fact that it often assumes alone the status of objectal representation in the work of formalisation?

It is because, as an object and as a practice, language presents a conjunction of characteristics which, when fantasised, are as many explanatory factors for this primacy. 
${ }^{10}$ This myth is even found within science. The main theories of meaning - whether it is semiotics, philosophy of language or functional linguistics - start from the axiom of conventionality: they invoke, implicitly or explicitly, a prior agreement to any communication, resting on a code outside of individual consciousness and that would be imperatively imposed to the partners of the exchange. Here lies, dressed with the clothing of science, the common conception in development in the harderian thought: language generates communion. This unanimist sociological conception was that of the founder of modern linguistics, Ferdinand de Saussure, influenced by Durkheim. It plays an obvious ideological role; it produces indeed the idea that speakers, subject to the same constraints, are interchangeable, and thus equal. It is to say the least that this linguistics, like about all the others, "sidesteps the question of the economic and social conditions of the acquisition of the legitimate competence and of the constitution of the market in which this definition of the legitimate and the illegitimate is established and imposed" (BOURDIEU, 1982, p. 25).
From this point of view, the first characteristic of language is its salience. It is because it allows the formulation of very apparent oppositions that it distinguishes groups in conflict of economic or ideological interest. Since identity is a structural relationship, it necessarily mobilises visible signs. But language, as an instrument of communication, is also a barrier, an alterity, a demarcation. This impermeability, which is its second characteristic, is both protection and differentiation: it shows its incomparable character to the eyes of those who come into contact with the language of the Other. And irreducibility and incommensurability are the characteristics of national culture according to Herder. Finally, there is a third factor: unanimity, another great linguistic myth ${ }^{10}$.

This explains the mystifying power of collective identities built on language: mobilising on the dogma of unanimity, they disguise divergences, differences and cleavages within the community, but at the same time use these divergences to stratify the social body.

\section{The identity moment}

But if we clearly see the function that a An Identity definition of the Francophone can play, it remains to be explained why this second Francophone was born, like the second Francophonie, in the 1970s.It will be observed that this birth is contemporary with an important cultural change: the one that was brought about by the economic turnaround following the great oil shock of 1973 and the structural crisis of capitalism that followed it, and is continuing before our eyes. A new cultural paradigm has emerged which I have described elsewhere (KLINKENBERG, 1985) and which, following Christopher Lasch (1979), I called the culture of narcissism.

After the economically brilliant 1960s, inhabited by generous utopias, a period of disillusionment began. The idea was questioned that the individual could exercise real control over his existence; the disciplines that gave him this impression - from the philosophy of history to economics - were deemed bankrupt, powerless to account for the new forms that the phenomena they professed to elucidate were taking. But the demand for meaning has to be satisfied. 
The insignificance of existence was therefore, in the 1980s, compensated for by an exclusive attention to the self. Personal and biographical time is once again given pride of place.

Back to the individual, therefore, but also to the groups that are supposed to define him. Nourishing impulses of withdrawal - failing to receive the security expected from communities deemed too vast in space or time - the contemporary individual values the groupings that may be the convenient metaphor of his or her self. Should we then be surprised by a movement that puts a high price on everything that compensates insignificance by creating meaning, on everything that stops dissolution by creating identity? Among these rising values are a number of symbolic values, such as that offered by language. However, in some communities, as we shall see, language cannot offer itself as a refuge.

Shaped by the economic fragility of many strata of society in a context of dualisation as much as by the new media situation, this culture is therefore characterised as much by individualism as by communitarianism. All trends which, for good or ill, reinforce identity traits and act as a counterbalance to the integration movement that dominates at the global level. And, although it is not a regional identity but, on the contrary, claims universality, the Francophone identity is precisely thought of as an alternative to that produced by the globalisation movement.

\section{A second identity}

However, it should be stressed here that if being francophone is an identity, this identity comes very logically second: one is first of all Acadian, Quebecois, 'French-speaking from the Brussels periphery', Senegalese, and then only 'French-speaking' for short. A second, but not secondary, character: not only does the identity discourse, as we have seen, make it possible to radicalise social oppositions (as do identities based on factors other than language), but above all, this second identity gives extension and legitimacy to the first, and constitutes a kind of meta-identity. By suggesting the possibility of the widest possible exchange, it confirms what one is oneself. This linkage is a possibility, not a necessity: in laboratories such as the Creole countries, for example, the 
speaker is in contact with the major world languages (English, Mandarin, Hindi, Arabic, etc.), which means that he or she is immediately involved in questions of identity, without having to resort to any francophone fantasy.

However, if this recourse appears to be useful, this meta-identity can play an important role in minority circles, to which it can provide a form of symbolic protection. So much so that the expression "francophone minority" will appear as a quasi-pléonasm in the eyes of some. As a corollary, it is easy to understand why the Frenchman is not - can never be - a "francophone". Having been nourished by universality, he directly experiences the fullness of being; he is therefore exempted from having to resort to the adjuvant that this identity represents.

\section{The making of the Francophone. An Act III?}

I approach this third phase in the form of an open question, for two reasons. The first is the strength of the identity current whose birth was observed in the second phase, a strength that derives in part from its crystallisation in institutions, and which guarantees its longevity. The second is that while this third phase allows us to observe a series of mutations in the linguistic values mobilised in the discourse on the French-speaking world, these mutations are, for reasons we shall see, less frankly accused than those observed in the discursive construction of the French-speaking world. So this third act may appear as a simple extension of the second.

The said mutations are facets - which will be detailed in the next three sections - of one and the same phenomenon: the appearance in epilinguistic discourse of a valorisation of new centrifugal forces. This valorisation tends to reproduce the strategies of the discourse of cultural diversity carried out by the French-speaking world during its third phase of development. However, the linguistic discourse is stated with less force than the latter, because it does not have the support of an institutional apparatus comparable to that of organised francophonie, an apparatus whose ideology is solidly backed by a defensive policy of the French-speaking states. 


\section{The school and local cultures}

I have been able elsewhere (KLINKENBERG, 2008) to formulate the hypothesis that the creation of the notion of endogenous norm, launched on the market by Gabriel Manessy $(1992,1997)$, and above all the very elaboration and exploitation of such norms, constitute a bundle of phenomena that correspond to the advent of new social groups, elaborating new values that correspond to their interests.

But it must be stressed here that the petty bourgeoisie, which emerged in the post-war period in Western societies as a result of the tertiarisation of the economy, is today more fragile than ever, threatened with downgrading by the movement of dualisation of these societies. And we know that this fragile group is particularly sensitive to linguistic insecurity. It would be interesting to ask whether the development of endogenous norms might not represent, for the same social group, the implementation of the option of innovation described by sociology as one of the possible solutions to deviance offered to this group (MERTON, 1966).

Moreover, since geographical factors are known to be important in the context of the French-speaking world, the advent of new cultural products (such as 'francophone literature') are also clearly part of this overall innovation process: they clearly correspond to the emergence of new social groups and the manifestation of new dynamics. One example is the particular contextualising factor of the school environment. This has been affected by a major change: the consideration of local cultures. (Times are no longer the same as they were for "our ancestors the Gauls"). And this centrifugal movement is all the more spectacular in that school systems, all of which are affected by the legitimacy of the local, vary widely in the French-speaking world, as does the place of language varieties - such as Creole - in these systems. It is a fact that the establishment or highlighting of endogenous standards does not correspond to the same issues everywhere: whether in the Congo, Tunisia, Acadia, Wallonia or Reunion Island, the concept corresponds each time to academic, political or educational realities which cannot be accounted for in a single formula. The very breakdown of these issues is, moreover, 
an overall justification for the existence of the concept of endogenous norm.

\section{The weakening of the centralising discourse}

The crisis producing narcissism has, as we have seen above, produced centrifugal movements. The linguistic counterpart of these movements is visible: the ideology of linguistic unification and centralisation is losing its vigour. And this requires a reformulation of the discourse described above as essentialist (which does not mean, of course, that the very process of centralisation is no longer at work or that this ideology is in the throes of collapse). For example, a study of the legitimising role played by common lexicographical tools (dictionaries, databases) indicates that varieties defined by a geographical parameter are now less stigmatised (cf. KLINKENBERG, 2002). This legitimisation of diatopic variation could not fail to generate a new discourse, justifying the centrifugal forces at work.

\section{The impact - despite everything - of the Francophonie}

This ideological factor can only be properly assessed in the context of calculating the impact that the rise of the francophonie has on the consciousness on the francophone. And this rise is a third factor in changing values.

Taking francophonie world seriously means admitting that French is plural, both in its forms and in its ability to express new realities. Although it may have long been believed that there was a single French Language, this is becoming difficult, except at the cost of real contortions, in a framework such as this.

But the rise in strength of the francophonie is having two contradictory effects. On the one hand, generating the relativism we have just mentioned, it gives rise to a movement of appropriation of the language, of which the concept of endogenesis is a good expression. French-speakers also know that they are no longer alone in the world, and that a certain form of solidarity is promised to them. Confidence. But on the other hand, he discovers in his language a face he did not know. He realizes that it is no longer his alone, since others are claiming co-ownership of it. He is forced to change his most 
indurated reflexes. Discomfort. This relativism is demanded of him at the very historical moment when he has the greatest need for security, the security offered by the fantasy model of a unified and stable Language...

All in all, the francophone sees itself as the custodian of a double heritage: a local heritage that is finally valued, and a universal heritage. The synthesis between these two tendencies remains problematic, condemning him to a (slight?) form of schizophrenia. However, the fate of the francophone today is never more than a particular manifestation of the fundamental ambiguity of the concept of francophonie (on which I ended my § 2); an ambiguity to which we are returning.

\section{Conclusion: to put an end to decorum}

The common point between the two discourses we have studied - the discourse of and on the francophonie, the discourse of and about the francophone - is obviously their essentialism. An essentialism that the researcher obviously cannot live with: it is incumbent upon him and the community to which he belongs to make an object of knowledge out of what has until now been a product of ideology.

It is therefore urgent for him to develop a theoretical battery of concepts that will enable him to thwart the game of myths and rituals. This requirement, which produces the general, goes hand in hand with another: respect for the particular. It will therefore be a question of giving him the means to account for the specificities of each of the cultural areas he visits. To do this - alas or fortunately: it depends - he will have to sacrifice unanimity, which seems to be the rule of cardinal propriety in francophone studies, to highlight the social power relations in each of these fields. Which is perhaps a way of recognising - modestly - that his discourse is also an ideology ... 


\section{REFERENCES}

AAVV. Le Français en France et hors de France. Actes du colloque sur les ethnies francophones. I. Créoles et contacts africains; II. Les français régionaux. Le français en contact, Paris: Minard (tome 1), 1969, Paris: Les Belles Lettres (tome 2), 1971.

BAGGIONI, Daniel; CALVET, Louis-Jean; CHAUDENSON, Robert; MANESSY, Gabriel; ROBILLARD, Didier de. Multilinguisme et développement dans l'espace francophone. Paris: Didier, 1992.

BOURDIEU, Pierre. Ce que parler veut dire. Paris: Fayard, 1982.

CHAUDENSON, Robert. Propositions pour une grille d'analyse des situations linguistiques de l'espace francophone. Paris: ACCTIECF, 1988.

La Francophonie : représentations, réalités et perspectives, AixenProvence: Institut d'études créoles et francophones de l’Université de Provence, 1991.

; RAKOTOMALALA, Dorothée. Situations linguistiques de la Francophonie. Paris: AUF, 2004.

GLASZE, Georg. The Discursive Constitution of a WorldSpanning Region and the Role of Empty Signifiers: The Case of Francophonia. Geopolitics, 12, 4, p. 656-679 (n. spe. Strategic Regionalisations: New Perspectives on Regions in a Global System), 2006.

. Compte-rendu de «Erfurt, Jürgen, Frankophonie: Sprache - Diskurs - Politik», H-Soz-u-Kult, H-Net Reviews in the Humanities and Social Sciences, mai 2006.

. Politische Räume. Die diskursive Konstitution eines "geokulturellen Raums ». Die Frankophonie, Bielefeld, Transcript Verlag (Perfect Paperback), 2010.

KLNKENBERG, Jean-Marie. Le Discours identitaire : une réponse narcissique à la crise ?. In: BAWIN, Bernadette; PICHAULT, François ; VOISIN, Marcel (org.), La Crise dans tous ses états. Actes du colloque de l'Association des sociologues belges de 
langue française, 1984, Faculté de Droit, d'économie et de sciences sociales de l'Université de Liège, Louvain-la-Neuve, CIACO, 1985, p. 185-194.

Langue et le citoyen. Pour une autre politique de la langue française, Paris: Presses universitaires de France (coll. La politique éclatée), 2001.

La Légitimation de la variation linguistique. L'information grammaticale, n. 94, juin 2002 [numéro spécial La langue française au XXe siècle], p. 22-26.

Normes linguistiques, normes sociales, endogenèse. Introduction. In: BAVOUX, Claudine; PRUDENT, LambertFélix ; WHARTON, Sylvie (org.). Normes endogènes et plurilinguisme. Aires francophones, aires créolophones, Lyon: ENS Éditions, 2008, p. 17-32.

Langue et identité. Langues et identités régionales. In: COURTOIS, Luc; PIROTTE, Jean; LEMAÎTRE, Sofia (org.). Apports de l'histoire aux constructions identitaires. Appartenances, frontières, diversité et universalisme, Louvain-la-Neuve: Fondation wallonne P.-M. et J.-F. Humblet (Publications de la Fondation wallonne P.-M. et J.-F. Humblet, série Recherches, 6), 2013, p. 53-73.

. Des études françaises aux études francophones. Chances et hypothèques. In : VAN BEVEREN, Julien (org.). Littérature, langue et didactique. Hommages à Jean-Louis Dumortier. Namur: Université de Namur, Diptyque, 2014, p. 83-108.

La Langue dans la cité. Vivre et penser l'équité culturelle. Bruxelles: Les Impressions nouvelles, 2015.

LASCH, Christopher. Le Complexe de Narcisse. Paris: Laffont, 1979.

MANESSY, Gabriel et al. Norme endogène et normes pédagogiques en Afrique noire francophone. In: BAGGIONI, Daniel; CALVET, Louis-Jean; CHAUDENSON, Robert; MANESSY, Gabriel; ROBILLARD, Didier de. Multilinguisme et développement dans l'espace francophone. Paris: Didier, 1992, p. $43-81$. 
Norme endogène. In: MOREAU, Marie-Louise (org.). Sociolinguistique. Concepts de base. Liège: Mardaga (coll. SH), 1997, p. 223-225.

MURAIS, Jacques; DUMONT, Pierre; KLINKENBERG, JeanMarie; MAURER, Bruno; CHARDENET, Patrick (org.). L'Avenir $d u$ français. Paris: Agence universitaire de la Francophonie, Édition des Archives Contemporaines, 2008.

MAURER, Bruno. Pour de nouvelles représentations du français dans la modernité. In: MURAIS, Jacques; DUMONT, Pierre; KLINKENBERG, Jean-Marie; MAURER, Bruno; CHARDENET, Patrick (org.). L'Avenir du français. Paris: Agence universitaire de la Francophonie, Édition des Archives Contemporaines, 2008, p. 139-141.

MOREAU, Marie-Louise (org.). Sociolinguistique. Concepts de base. Liège: Mardaga (coll. SH), 1997.

MERTON, Robert King. Éléments de théorie et de méthode sociologique. Paris: Plon (coll. Recherches en sciences humaines), 1966.

PROVENZANO, François. Francophonie et études francophones : considérations historiques et métacritiques sur quelques concepts majeurs. Journal of multidisciplinary international studies, v. 3, n. 2, 2006.

. Vies et mort de la francophonie. Une politique française de la langue et de la littérature. Bruxelles: Les Impressions nouvelles, 2011a.

Historiographies périphériques. Enjeux et rhétoriques de l'histoire littéraire en francophonie du Nord (Belgique, Suisse romande, Québec). Bruxelles: Académie royale de Belgique, coll. Classe des lettres, $2011 b$.

RACELLE-LATIN, Danièle (org.), Inventaire des particularités lexicales du français en Afrique noire. Montréal: AUPELF-A.C.C.T., 1983.

RECLUS, Onésime. France, Algérie et colonies. Paris: Hachette, 1880. . La France et ses colonies. Paris: Hachette, 1889. . Le plus beau royaume sous le ciel. Paris: Hachette, 1899 
ROBILLARD, Didier de; BENIAMINO, Michel (org. avec Claudine Bavoux pour le t. 2). Le Français dans l'espace francophone. Paris: Honoré Champion, 1993/1996.

VALDMAN, Albert (org., avec la coll. de Robert Chaudenson et Gabriel Manessy). Le Français hors de France. Paris: Honoré Champion, 1979.

WOLFF, Alexandre (org.). La Langue française dans le monde. Paris: Nathan, 2010. (org.), 2014. La Langue française dans le monde. Paris: OIF, Nathan, 2014.

\section{RESUMO}

\section{A produção do francofono: uma construção discursiva}

A presente pesquisa apresenta, por um lado, uma análise discursiva das principais fases na evolução do discurso sobre o mundo francófono $e$, por outro, sobre o falante francófono: quando esses dois objetos estão sendo constituídos, uma forte convergência entre eles aparece, seguida por uma divergência espetacular; uma divergência que produzirá ambiguidades e confusões, cujos efeitos nas representações, posições e ações serão estudados. O estudo conclui que é necessário levar em consideração as características específicas de cada uma das áreas culturais da francofonia.

Palavras-chave: Francofonia. Análise discursiva. Evolução histórica. Ideologia.

Jean-Marie Klinkenberg é Doutor em Filologia Românica pela Universidade de Liège, na Bélgica. Professor Emérito e um dos fundadores do Grupo $\mu$, da mesma universidade. Membro da Academia Real da Bélgica. Presidiu a Associação Internacional de Semiótica Visual. Suas atividades profissionais se concentram em duas áreas: linguística/semiótica e culturas francófonas. 